\title{
Article \\ Retrospective Analysis of Functional Pain among Professional Climbers
}

\author{
Matuska Jakub ${ }^{1}$ (D) Jokiel Marta ${ }^{2,3}$, Domaszewski Przemysław ${ }^{4}$, Konieczny Mariusz ${ }^{5}$ (D) Pakosz Paweł ${ }^{5}$ (D), \\ Dybek Tomasz $^{5}$, Wotzka Daria ${ }^{6}$ (D) and Skorupska Elżbieta ${ }^{2,5, *(\mathbb{D})}$
}

check for

updates

Citation: Jakub, M.; Marta, J.;

Przemysław, D.; Mariusz, K.; Paweł, P.; Tomasz, D.; Daria, W.; Elżbieta, S. Retrospective Analysis of Functional Pain among Professional Climbers. Appl. Sci. 2022, 12, 2653. https:// doi.org/10.3390/app12052653

Academic Editors: Szczepan Paszkiel, Ningrong Lei and Maria António Castro

Received: 12 January 2022

Accepted: 2 March 2022

Published: 4 March 2022

Publisher's Note: MDPI stays neutral with regard to jurisdictional claims in published maps and institutional affiliations.

Copyright: (c) 2022 by the authors. Licensee MDPI, Basel, Switzerland. This article is an open access article distributed under the terms and conditions of the Creative Commons Attribution (CC BY) license (https:// creativecommons.org/licenses/by/ $4.0 /)$.
1 PHU Technomex, 44-141 Gliwice, Poland; jakubmatuska.20@gmail.com

2 Department of Physiotherapy, Poznan University of Medical Sciences, 61-701 Poznań, Poland; marta.jokiel@ump.edu.pl

3 Department of Traumatology, Orthopedics and Hand Surgery, Poznan University of Medical Sciences, 60-761 Poznań, Poland

4 Department of Health Sciences, Institute of Health Sciences, University of Opole, 45-040 Opole, Poland; przemyslaw.domaszewski@uni.opole.pl

5 Faculty of Physical Education and Physiotherapy, Opole University of Technology, 45-758 Opole, Poland; m.konieczny@po.edu.pl (K.M.); p.pakosz@po.edu.pl (P.P.); t.dybek@po.edu.pl (D.T.)

6 Faculty of Electrical Engineering Automatic Control and Informatics, Opole University of Technology, 45-758 Opole, Poland; d.wotzka@po.edu.pl

* Correspondence: skorupska@ump.edu.pl

\begin{abstract}
Climbing became one of the official Olympic sports in 2020. The nociplastic pain mechanism is indicated as important in professional sports. Functional pain, which has not been examined in climbers until now, can be an example of nociplastic pain. This study aimed to determine functional pain locations in climbers according to gender and dominant climbing style. Climbers $(n=183)$ and healthy subjects $(n=160)$ completed an online survey focused on functional pain occurrence in the head, spine, and upper limbs. The logistic regression showed that climbing predisposes one to functional pain at: Gleno-humeral joint (odds ratio (OR): 3.06; area under the curve (AUC): 0.635), elbow (OR: 2.86; AUC: 0.625), fingers (OR: 7.74; AUC: 0.733), all ( $p<0.05)$. Among the climbers, the female gender predisposed one to pain at: GHJ (OR: 3.34; AUC: 0.638), thoracic spine (OR: 1.95; AUC: 0.580), and lumbosacral spine (OR: 1.96; AUC: 0.578), all $(p<0.05)$. Climbing predisposes one to functional pain development in the upper limb. While the male climbers mainly suffered from finger functional pain, the female climbers reported functional pain in the GHJ and the thoracic and lumbosacral spine. Further studies on functional pain occurrence are recommended.
\end{abstract}

Keywords: climbing; bouldering; athletes; functional pain; pain prevalence; upper limb

\section{Introduction}

Climbing became one of the official Olympic sports in 2020. It consists of three disciplines: lead climbing, bouldering, and speed climbing [1]. The main difference between these disciplines is the height of the wall and the use of protective gear in lead climbing. Moreover, bouldering requires more dynamic moves than lead climbing [2,3]. Due to these differences, some distinctive features have been confirmed among competitors, e.g., boulderers show a higher maximal and explosive strength than lead climbers [3]. Therefore, the time taken to complete a climbing route in lead climbing is 4-14 times longer than in bouldering. It has also been shown that the percentage of eccentric contractions during a performance is lower in lead climbing [4]. Bad technique habits or the discipline of climbing can contribute to the additional overloading of soft tissue, which can consequently become a source of pain, as in the case of injury [5].

In 2017, the International Olympic Committee issued recommendations on pain management that include a need for therapeutic interventions to be used in addition to and/or instead of the pharmacological treatment of pain [6]. Moreover, the possible importance of 
a new pain subtype, i.e., nociplastic pain, which demands a different therapeutic approach and prophylactics, has been indicated [6]. The main characteristics of this pain pathomechanism include a widespread pain area compared to the anatomical region, evoked pain hypersensitivity phenomena, and the history of pain or hypersensitivity comorbidities leading to pain chronicity and/or a recurrent pain state [7]. It seems possible that athletes who suffer from functional pain (without a detectable organic cause [8]) can be classified as nociplastic pain cases. Nociplastic pain is diagnosed based on clinical assessment, pain characteristics, and results of the Central Sensitization Inventory [7]. However, it has been suggested that this questionnaire seems to be useless for musculoskeletal pain related to nociplastic pain [9]. There is an absence of studies specifying the characteristic areas of functional pain in most sports, not only in climbing. It can be presumed that functional pain can be one of the possible risk factors predisposing one to injury. In the literature, the risk factors that may predispose climbers to be injured can be divided into intrinsic (e.g., sex, age, experience, and proficiency) and extrinsic (e.g., climbing intensity or indoor/outdoor climbing) [10]. Another interesting issue is whether the type of climbing has meaning for functional pain development [6].

There is a lack of data that describe chronic pain characteristics among athletes, including climbers [6]. This knowledge is essential for setting up prevention programs and undertaking future studies on medical management for climbers. Factors such as gender or the dominant form of climbing may affect the most frequent anatomical locations of pain. Due to actual knowledge, we can expect that the results will indicate that gender, type of climbing, and level of performance may have an influence on the presence of functional pain.

The aim of this explorative study is to identify the characteristic locations of functional pain in climbers by gender and dominant climbing style.

\section{Materials and Methods}

\subsection{Study Design and Participants}

This observational, retrospective study involved a group of 464 participants composed of two hundred and twenty-two climbers $(n=222)$ and two hundred and forty-two $(n=242)$ non-climbers. The final number of participants and group division are presented in the flow chart (Figure 1). Participants were excluded from the control group if they participated in sports and from the climbers' group if they had been climbing actively for less than a year.

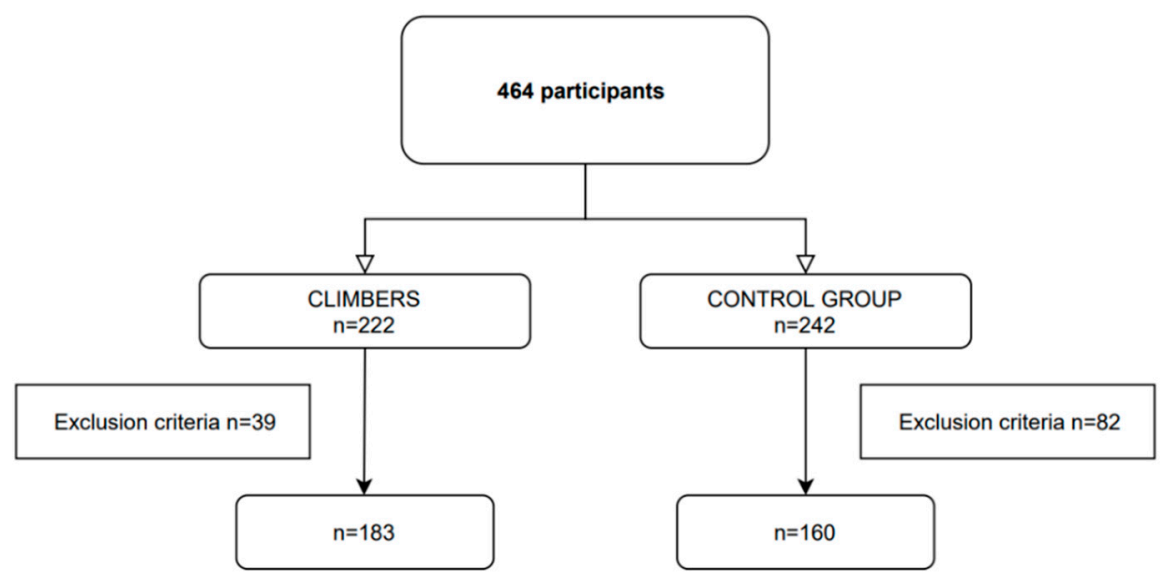

Figure 1. A flow diagram of the study design.

The inclusion criteria for the climbers' group were: age $\geq 18$ and active climbing (bouldering or lead climbing) for more than a year. A lack of consent to participate in the study and a current acute injury were the exclusion criteria for the climbers. The control group $(n=160)$ consisted of healthy females and males that were not involved in any sports 
and lived in Poland. The demographic data of this group are presented in Table 1. The main inclusion criterion for the healthy subjects was age $\geq 18$. The respondents from the control group were excluded if they: participated in sports, refused to give their consent to take part in the study, or suffered from a current acute injury.

Table 1. Demographic data of the control and climbers' groups.

\begin{tabular}{|c|c|c|c|}
\hline Variable & $\begin{array}{c}\text { Climbers } \\
n=183\end{array}$ & $\begin{array}{l}\text { Control } \\
n=160\end{array}$ & $p$-Value \\
\hline Female; \% (n) & $47.54(87)$ & $56.25(90)$ & \multirow{2}{*}{$0.061^{* * *}$} \\
\hline Male; \% (n) & $52.46(96)$ & $43.75(70)$ & \\
\hline $\begin{array}{l}\text { Age; mean } \pm \text { SD } \\
\quad \text { (range); }\end{array}$ & $\begin{array}{l}30.21 \pm 7.25 \\
\quad(18-59)\end{array}$ & $\begin{array}{l}28.98 \pm 7.89 \\
\quad(20-64)\end{array}$ & 0.133 ** \\
\hline $\begin{array}{c}\text { Height }(\mathrm{cm}) ; \text { mean } \pm \text { SD } \\
\text { (range); }\end{array}$ & $\begin{array}{l}172.85 \pm 9.26 \\
(154-200)\end{array}$ & $\begin{array}{l}173.52 \pm 9.19 \\
(150-200)\end{array}$ & $0.501^{* *}$ \\
\hline $\begin{array}{c}\text { Weight }(\mathrm{kg}) ; \text { mean } \pm \mathrm{SD} \\
\text { (range); } \\
\operatorname{Me}(\mathrm{Q} 1: \mathrm{Q} 4) *\end{array}$ & $\begin{array}{l}65.78 \pm 11.36 \\
(40-98) \\
64(57: 74)\end{array}$ & $\begin{array}{c}72.7 \pm 16.47 \\
(45-140) \\
70(60: 83)\end{array}$ & $<0.001$ * \\
\hline $\begin{array}{c}\text { BMI; mean } \pm \text { SD } \\
(\text { range }) ; \\
\text { Me }(\mathrm{Q} 1: Q 4)^{*}\end{array}$ & $\begin{array}{c}21.70 \pm 2.44 \\
(16.44-29.07) \\
21.33(20.19: 23.24)\end{array}$ & $\begin{array}{c}24.24 \pm 4.67 \\
(16.9-42.27) \\
23.19(20.88: 27.01)\end{array}$ & $<0.001$ * \\
\hline
\end{tabular}

* Mann-Whitney U test, ${ }^{* *}$ Student's $t$-test, ${ }^{* * *}$ chi-square test.

The chi-square test showed that both the study and the control group were in equilibrium. There were no significant differences in gender, type of climbing, and level of experience between the compared groups. Additionally, there was no significant difference in hours per week of climbing between the males $(4.93 \pm 0.19)$ and the females $(4.89 \pm 0.26)$, as well as between the intermediate $(4.81 \pm 0.31)$ and the experienced $(4.98 \pm 0.23)$ climbers. The Body Mass Index of the participants was within normal limits.

The performance level (intermediate, experienced) in climbing was set for each participant based on the route difficulty achieved over the last year, according to Grønhaug and Norberg [11]. For the intermediate climbers, the route difficulty was as follows: (i) boulderers: $6 \mathrm{~A}$ to $6 \mathrm{C}+$; (ii) lead climbers: $6 \mathrm{~b}+$ to $7 \mathrm{a}+$. For the experienced climbers, it was: (i) boulderers: $7 \mathrm{~A}$ to $7 \mathrm{C}$; (ii) lead climbers: $7 \mathrm{~b}$ to $8 \mathrm{~b}$.

\subsection{Procedures}

Each of the participants completed an online questionnaire using Google Forms. The main study was preceded by a pilot test. Those taking part in the pilot $(n=20)$ were not included in the main sample. The subjects that participated in the pilot did not have any doubts about the questions. The final questionnaire was composed of single-choice, multiple-choice, and open-ended questions that were divided into five sections. The climbers completed the full version of the questionnaire, whereas the control group was asked to omit Sections Two and Five that contained the questions on climbing.

The survey was available via social media and via email from February to July. Upon accessing the survey, the respondents were presented with instructions. Then, after giving their consent, they could start the survey. All the procedures were conducted in accordance with the principles set forth in the Declaration of Helsinki.

The final questionnaire consisted of:

- Section One on demographic data;

- Section Two on training behaviors;

- Section Three on musculoskeletal pain that occurred in the participants;

- $\quad$ Section Four on injuries in the past;

- $\quad$ Section Five with questions about the technique and biological regeneration methods used by the climbers, as well as three ROM (range of movement) tests that the partici- 
pants performed at home (Apley scratch tests for both external and internal rotation and chain to sternum movement).

\subsection{Statistical Analysis}

Data were summarized using the mean (standard deviation), counts (percentages), and median if needed. A logistic regression analysis was performed to investigate if there was: (a) a relationship between the prevalence of functional pain and climbing; (b) in the climbers' group, a relationship between the prevalence of functional pain and the following predictors: gender, type of climbing, and level of performance. The $p$ values were adjusted for multiple comparisons using the Benjamini-Hochberg correction method. The chi-square test was used to investigate intra-group and extra-group differences in functional pain occurrence. The area under the curve (AUC) was used as a measure of effect size. The demographic data were analyzed using chi-square, Student's $t$-test, and the Mann-Whitney $\mathrm{U}$ test. The sample size for each group was set at 365 by using the sample size formula for an infinite population with $\alpha=0.05, \mathrm{CI}$ (Confidence Interval) $=95 \%$, and margin of error of $5 \%$ (for fraction $50 \%$ ). The value of statistical significance was set at $p<0.05$. Statistical analysis was performed using R version 4.1.2 and PQstat 1.8.2.

\section{Results}

\subsection{Functional Pain Characteristics of the Climbers' and Control Groups}

The logistic regression analysis considered the functional pain characteristics depending on the sports activity and anatomical body part. The results showed that the climbers were three times more likely to experience functional pain in the GHJ (gleno-humeral joint) (AUC: 0.635 ) and had 2.86 times higher odds of developing functional pain in the elbow (AUC: 0.625 ) and 7.74 times higher odds for functional pain occurrence in the fingers (AUC: 0.733).

Moreover, the results revealed that the climbers suffered less often from functional back pain than the control group. The analysis of other regions showed no significant meaning. Detailed data are shown in Table 2.

Table 2. Results of the logistic regression model that was used to predict the differences between the climbers and non-climbers in the anatomical location of functional pain.

\begin{tabular}{|c|c|c|c|c|c|c|}
\hline $\begin{array}{c}\text { Anatomical } \\
\text { Location of } \\
\text { Functional Pain }\end{array}$ & Predictors & $\begin{array}{l}\text { Odds } \\
\text { Ratio }\end{array}$ & $\begin{array}{l}\text { Std. } \\
\text { Error }\end{array}$ & CI & $\begin{array}{c}p \\
\text { (Adjusted) }\end{array}$ & AUC \\
\hline \multirow[b]{2}{*}{$\mathrm{GHJ}$} & (Intercept) & 0.48 & 0.17 & $0.35-0.67$ & $<0.001 *$ & - \\
\hline & $\begin{array}{l}\text { Climbing } \\
(\text { yes }=1)\end{array}$ & 3.06 & 0.23 & $1.96-4.77$ & $<0.001$ * & 0.635 \\
\hline \multirow[b]{2}{*}{ Elbow } & (Intercept) & 0.26 & 0.20 & $0.18-0.38$ & $<0.001 *$ & - \\
\hline & $\begin{array}{l}\text { Climbing } \\
(\text { yes }=1)\end{array}$ & 2.86 & 0.25 & $1.77-4.63$ & $<0.001$ * & 0.625 \\
\hline \multirow[b]{2}{*}{ Fingers } & (Intercept) & 0.30 & 0.19 & $0.21-0.43$ & $<0.001 *$ & - \\
\hline & $\begin{array}{c}\text { Climbing } \\
(\text { yes }=1)\end{array}$ & 7.74 & 0.25 & $4.76-12.56$ & $<0.001 *$ & 0.733 \\
\hline \multirow[b]{2}{*}{$\mathrm{C}$} & (Intercept) & 1.76 & 0.16 & $1.27-2.43$ & $<0.001 *$ & - \\
\hline & $\begin{array}{l}\text { Climbing } \\
(\text { yes }=1)\end{array}$ & 0.28 & 0.23 & $0.18-0.43$ & $<0.001$ * & 0.345 \\
\hline \multirow[b]{2}{*}{ Th } & (Intercept) & 1.46 & 0.16 & $1.07-2.00$ & $0.019 *$ & - \\
\hline & $\begin{array}{c}\text { Climbing } \\
(\text { yes }=1)\end{array}$ & 0.35 & 0.22 & $0.23-0.54$ & $<0.001 *$ & 0.372 \\
\hline
\end{tabular}


Table 2. Cont.

\begin{tabular}{|c|c|c|c|c|c|c|}
\hline $\begin{array}{c}\text { Anatomical } \\
\text { Location of } \\
\text { Functional Pain }\end{array}$ & Predictors & $\begin{array}{l}\text { Odds } \\
\text { Ratio }\end{array}$ & $\begin{array}{l}\text { Std. } \\
\text { Error }\end{array}$ & CI & $\begin{array}{c}p \\
\text { (Adjusted) }\end{array}$ & AUC \\
\hline \multirow[b]{2}{*}{ L-S } & (Intercept) & 2.08 & 0.17 & $1.49-2.89$ & $<0.001 *$ & - \\
\hline & $\begin{array}{c}\text { Climbing } \\
(\text { yes }=1)\end{array}$ & 0.31 & 0.23 & $0.20-0.49$ & $<0.001 *$ & 0.360 \\
\hline \multirow[b]{2}{*}{ Head } & (Intercept) & 4.33 & 0.20 & $2.91-6.45$ & $<0.001$ * & - \\
\hline & $\begin{array}{c}\text { Climbing } \\
(\text { yes }=1 \text { ) }\end{array}$ & 0.07 & 0.27 & $0.04-0.11$ & $<0.001$ * & 0.207 \\
\hline
\end{tabular}

${ }^{*} p<0.05$; GHJ—glenohumeral joint, C—cervical spine, Th—thoracic spine, L-S-lumbosacral spine.

Additionally, the multiple logistic regression results revealed that the female climbers had more than twice lower odds of developing functional pain in the fingers compared to the male climbers (AUC: 0.385 ). The female climbers were more than three times as likely to develop pain in the GHJ compared to the male climbers (AUC: 0.638). Furthermore, the odds for pain prevalence in the thoracic (AUC: 0.580) and lumbosacral spine (AUC: 0.578) were nearly twice as high in the female climbers than in the male climbers (Table 3 ).

Table 3. Results of the logistic regression model that was used to predict pain among the climbers depending on gender, type of climbing, and level of performance.

\begin{tabular}{|c|c|c|c|c|c|c|}
\hline $\begin{array}{c}\text { Anatomical } \\
\text { Location of } \\
\text { Functional Pain }\end{array}$ & Predictors & Odds Ratio & Std. Error & CI & $p$ (Adjusted) & AUC \\
\hline \multirow{4}{*}{ GHJ } & (Intercept) & 0.53 & 0.17 & $0.28-0.99$ & $0.048 *$ & - \\
\hline & Gender $($ female $=1)$ & 3.34 & 1.12 & $1.74-6.44$ & $0.004^{*}$ & 0.638 \\
\hline & $\begin{array}{l}\text { Preferred style of } \\
\text { climbing }(\text { lead }=1)\end{array}$ & 2.04 & 0.67 & $1.07-3.88$ & 0.120 & 0.582 \\
\hline & $\begin{array}{l}\text { Performance level } \\
\qquad(\exp =1)\end{array}$ & 1.47 & 0.52 & $0.73-2.96$ & 0.438 & 0.510 \\
\hline \multirow{4}{*}{ Fingers } & (Intercept) & 2.54 & 0.85 & $1.32-4.88$ & 0.010 * & - \\
\hline & Gender $($ female $=1)$ & 0.41 & 0.14 & $0.21-0.81$ & 0.020 * & 0.385 \\
\hline & $\begin{array}{l}\text { Preferred style of } \\
\text { climbing }(\text { lead = 1) }\end{array}$ & 1.42 & 0.49 & $0.72-2.78$ & 0.409 & 0.528 \\
\hline & $\begin{array}{l}\text { Performance level } \\
\qquad(\exp =1)\end{array}$ & 1.96 & 0.77 & $0.90-4.25$ & 0.356 & 0.575 \\
\hline \multirow{4}{*}{ Thoracic spine } & (Intercept) & 0.27 & 0.09 & $0.14-0.51$ & $0.004^{*}$ & - \\
\hline & Gender $($ female $=1)$ & 1.95 & 0.65 & $1.02-3.73$ & $0.043 *$ & 0.580 \\
\hline & $\begin{array}{l}\text { Preferred style of } \\
\text { climbing }(\text { lead = 1) }\end{array}$ & 1.53 & 0.50 & $0.80-2.91$ & 0.396 & 0.550 \\
\hline & $\begin{array}{l}\text { Performance level } \\
\qquad(\exp =1)\end{array}$ & 1.32 & 0.47 & $0.66-2.65$ & 0.438 & 0.512 \\
\hline \multirow{4}{*}{ Lumbosacral spine } & (Intercept) & 0.45 & 0.14 & $0.25-0.83$ & 0.013 * & - \\
\hline & Gender $($ female $=1)$ & 1.96 & 0.62 & $1.05-3.64$ & $0.043 *$ & 0.578 \\
\hline & $\begin{array}{l}\text { Preferred style of } \\
\text { climbing (lead = 1) }\end{array}$ & 0.90 & 0.28 & $0.48-1.67$ & 0.739 & 0.487 \\
\hline & $\begin{array}{l}\text { Performance level } \\
\qquad(\exp =1)\end{array}$ & 1.32 & 0.45 & $0.68-2.59$ & 0.438 & 0.520 \\
\hline
\end{tabular}


The odds of developing functional pain in the GHJ among those who preferred lead climbing was 2.04 times higher than among those who preferred bouldering. However, it is worth noting that this difference was not statistically significant.

Logistic regression showed no relationship between the functional pain prevalence in other areas and the examined predictors (gender, type of climbing, and level of performance). Details are given in Table 3.

\subsection{Incidence of Functional Pain in the Cohort}

All participants in the climbers' group and the non-climbers group experienced functional pain in at least one of the concerned regions. In the climbers' group, the most frequent location of pain was the upper $\operatorname{limb}(95.11 \%, n=175)$, whereas among the non-climbers group, it was the back $(85 \%, n=136)$ (Table 4$)$.

Table 4. Prevalence of functional pain depending on the participation in climbing.

\begin{tabular}{|c|c|c|c|}
\hline Part of Body & Location of Pain & $\begin{array}{c}\text { Climbers } \\
n=183 \\
\%(n)\end{array}$ & $\begin{array}{c}\text { Control } \\
n=160 \\
\%(n)\end{array}$ \\
\hline \multirow{6}{*}{ Upper Limb } & GHJ & $59.56(109) *$ & $32.50(52)$ \\
\hline & Arm & $29.51(54)$ & $29.38(47)$ \\
\hline & Elbow & $42.62(78) *$ & $20.63(33)$ \\
\hline & Forearm & $23.50(43)$ & $21.88(35)$ \\
\hline & Hand & $33.33(61)$ & $35.00(56)$ \\
\hline & Fingers & $69.95(128)$ * & $23.13(37)$ \\
\hline \multirow{3}{*}{ Spine } & Cervical & $32.79(60)$ & $63.75(102)$ * \\
\hline & Thoracic & $33.88(62)$ & $59.38(95) *$ \\
\hline & Lumbosacral & $39.34(72)$ & $67.50(108)$ * \\
\hline \multicolumn{2}{|c|}{ Head } & $22.40(41)$ & $81.25(130)$ * \\
\hline
\end{tabular}

* $p<0.05$ chi 2 .

As demonstrated in Table 5, there were differences in pain occurrence in the intragroup and intergroup analysis performed using chi2. The female climbers often developed pain in the GHJ (73.56\%), elbow (44.83\%), and fingers (59.77\%), whereas the control group females reported the back $(\mathrm{C}=76.67 \%$; $\mathrm{Th}=73.33 \%$; $\mathrm{L}-\mathrm{S}=81.11 \%)$ and head $(88.42 \%)$ as the most frequent locations of functional pain. Next, the male climbers usually reported functional pain in the GHJ (46.88\%), elbow $(40.63 \%)$, and fingers $(79.17 \%)$, while the control group males indicated the cervical spine $(47.14 \%)$, thoracic spine $(41.43 \%)$, lumbosacral spine $(50.00 \%)$, and head $(65.71 \%)$ as the most common painful locations. In the control group, the women were more likely to develop back pain and headaches than the men (Table 5).

Table 5. Prevalence of functional pain depending on gender.

\begin{tabular}{|c|c|c|c|c|c|}
\hline Part of Body & $\begin{array}{c}\text { Anatomical } \\
\text { Location of } \\
\text { Functional Pain }\end{array}$ & $\begin{array}{c}\text { Female Climbers } \\
n=87(\%)\end{array}$ & $\begin{array}{l}\text { Male Climbers } \\
\qquad n=96(\%)\end{array}$ & $\begin{array}{l}\text { Female Control } \\
n=90(\%)\end{array}$ & $\begin{array}{c}\text { Male Control } \\
n=70(\%)\end{array}$ \\
\hline \multirow{6}{*}{ Upper Limb } & GHJ & $73.56(64)^{* \wedge}$ & $46.88(45)^{\wedge}$ & $40.00(36)$ & $22.86(16)$ \\
\hline & Arm & $27.87(24)$ & $31.25(30)$ & 33.33 (30) & 24.29 (17) \\
\hline & Elbow & $44.83(39)^{\wedge}$ & $40.63(39)^{\wedge}$ & $22.22(20)$ & $18.57(13)$ \\
\hline & Forearm & $25.29(22)$ & $21.88(21)$ & $24.44(22)$ & $18.57(13)$ \\
\hline & Hand & $31.03(27)$ & 35.48 (34) & $44.44(40) * *$ & $22.86(16)$ \\
\hline & Fingers & $59.77(52)^{\wedge}$ & $79.17(76)^{*} /{ }^{\wedge}$ & $25.56(23)$ & $20.00(14)$ \\
\hline
\end{tabular}


Table 5. Cont.

\begin{tabular}{|c|c|c|c|c|c|}
\hline Part of Body & $\begin{array}{c}\text { Anatomical } \\
\text { Location of } \\
\text { Functional Pain }\end{array}$ & $\begin{array}{c}\text { Female Climbers } \\
n=87(\%)\end{array}$ & $\begin{array}{c}\text { Male Climbers } \\
n=96(\%)\end{array}$ & $\begin{array}{l}\text { Female Control } \\
\qquad n=90(\%)\end{array}$ & $\begin{array}{c}\text { Male Control } \\
n=70(\%)\end{array}$ \\
\hline \multirow{3}{*}{ Spine } & Cervical & $35.63(31)$ & $30.21(29)$ & $76.67(69)^{* * / \wedge}$ & $47.14(33)^{\wedge}$ \\
\hline & Thoracic & $41.38(36) *$ & $27.08(26)$ & $73.33(66)^{* * / \wedge}$ & $41.43(29)^{\wedge}$ \\
\hline & Lumbosacral & $47.13(41)$ * & $32.29(31)$ & $81.11(73)^{* * / \wedge}$ & $50.00(35)^{\wedge}$ \\
\hline Head & & $28.74(26) *$ & $15.63(15)$ & $88.42(84)^{* *} / \wedge$ & $65.71(46)^{\wedge}$ \\
\hline
\end{tabular}

\section{Discussion}

This is the first study that has investigated the prevalence of functional pain in climbers. Additionally, the functional pain dependency on the athletes' proficiency, type of climbing, and gender was analyzed. The results of the study indicate that climbing increases the risk of functional pain in the following areas: GHJ, elbow, and fingers. The female gender is predisposed to functional pain in the GHJ, thoracic spine, and lumbosacral spine, while the male gender reports pain in the fingers. However, the type of climbing and level of performance had no impact on the occurrence of functional pain. Surprisingly, the risk of headaches and back pain in climbers is twice lower and almost twice lower, respectively, compared to the control group.

The current study results that demonstrate functional pain occurrence are consistent with the studies reporting injuries among climbers [11-16]. It has been suggested that the upper limbs are affected by climbing, and acute injuries of the lower limbs are caused by falls [15]. It seems probable that functional pain is a factor that precedes the onset of an injury in a particular region. The biomechanical studies of climbing proved that climbing results in specific adaptations to the musculoskeletal system, such as imbalance in capacity and the activation of antagonist muscles, especially in the upper limbs [17-19]. These factors may predispose one to soft tissue overloading and - consequently - to pain. The fact that functional pain has currently been classified as nociplastic pain can suggest a probable pain pathomechanism. However, to answer the question of whether functional pain depends on nociplastic pain characteristics, further studies focused on a more precise examination of nociplastic pain are required. Despite the International Olympic Committee's indication of the importance of nociplastic pain, little is known as regards its occurrence among athletes [6]. We do not know if the group presented in the study suffered from nociplastic pain.

It is not clear what causes the differences between male and female climbers. The occurrence of functional pain in various areas depending on gender may be explained by mechanical factors, the climbing technique and habits, or some other distinctive features of climbing, which can be different between males and females [20,21]. However, the etiological basis underlying these sex differences is unknown. The hormonal status is indicated as a possible explanation [22-25]. Moreover, the female predisposition to the asymptomatic form of trigger points in the lower limbs has been confirmed [26]. Thus, we can speculate that nociplastic pain among female climbers is possible.

The differences in pain as regards the type of climbing turned out to be statistically insignificant. Nevertheless, people who reported their preference for bouldering or lead climbing were included in the climbers' group. A possibility of examining a study group that only includes the climbers who perform one type of climbing or spend much more time on training one of the types of climbing should be taken into consideration. We conclude that further analysis is required.

The level of climbing performance seems to have no impact on the prevalence of functional pain among climbers. However, in this study, we used the scale of experience level suggested by Grønhaug and Norberg [11]. It does not take into account the intensity of climbing. The Climbing Intensity Score (CIS) should be considered instead as it includes 
age, days per year of climbing, and an average grade of climbing [27]. Perhaps using the CIS would show some differences between the intermediate and experienced climbers that should be examined in the future.

A higher prevalence of functional back pain observed in the control group may be due to sedentary lifestyles. Studies on physical activity and non-specific low back pain have shown that activities that include general exercise programs improve back pain [28]. Authors have reported that climbing has a positive impact on the lower back $[29,30]$. The lower prevalence of back pain in the climbers' group may be connected to the fact that climbing is the kind of sports that develops all motor skills and the whole body. A study that investigated the prevalence of back pain in overhead athletes suggested that the disciplines that involve the upper parts of the body may prevent back pain [31].

Future research should be conducted not only to assess the biomechanics of climbing but also to investigate the prevalence of nociplastic pain and its predictors among climbers.

\subsection{Clinical Relevance}

The clinical importance of this study is that the areas of functional pain are similar to those described in the studies where climbers reported injuries. In accordance with the International Olympic Committee, athletes must have professional healthcare, including pain management as a prophylactic of potential injuries.

Furthermore, the study showed various outcomes of functional pain prevalence dependent on gender. These differences should be considered in training and prophylactic programs to optimize climbers' performance.

\subsection{Limitations}

The promising results presented in this study were obtained based on a relatively small sample and, thus, require further comprehensive modeling in the future. Moreover, the climbers were assigned a grade according to the most difficult route they had climbed over the last year. In future research, the Climbing Intensity Score should be taken into account as it considers more factors. What is more, the preferred type of climbing should be more specified, as we suggested in the discussion. Additionally, the study did not consider the climbers' dominant side. Nevertheless, climbing is a symmetrical sport that includes both sides equally.

\section{Conclusions}

Climbing predisposes one to functional pain development in the upper limb. While the male climbers mainly suffered from finger functional pain, the female climbers reported functional pain in the GHJ and both the thoracic and the lumbosacral spine. Further studies on functional pain (including nociplastic pain) prevalence among climbers and its factors should be conducted.

Author Contributions: Conceptualization M.J. and J.M.; formal analysis D.T.; investigation M.J. and J.M.; writing—original draft preparation M.J., D.P. and K.M.; providing input for the analysis and interpretation of data M.J., P.P. and W.D.; supervision S.E. All authors have read and agreed to the published version of the manuscript.

Funding: This research received no external funding.

Institutional Review Board Statement: Ethical review and approval were waived for this study because it was not a medical experiment.

Informed Consent Statement: Informed consent was obtained from all the subjects involved in the study.

Data Availability Statement: The data are not publicly available due to data privacy regulations.

Acknowledgments: The authors thank all of the study participants and interpreters for generously helping in developing this study.

Conflicts of Interest: The authors declare no conflict of interest. 


\section{References}

1. Annual Report. IFSC. 2019. Available online: https://cdn.ifsc-climbing.org/images/ifsc/Footer/Annual_Reports/ifsc-annualreport-2019-final-website.pdf (accessed on 12 November 2021).

2. Stien, N.; Saeterbakken, A.H.; Hermans, E.; Vereide, V.A.; Olsen, E.; Andersen, V. Comparison of climbing-specific strength and endurance between lead and boulder climbers. PLoS ONE 2019, 14, e0222529. [CrossRef] [PubMed]

3. White, D.J.; Olsen, P.D. A time motion analysis of bouldering style competitive rock climbing. J. Strength Cond. Res. 2010, 24, 1356-1360. [CrossRef] [PubMed]

4. Billat, V.; Palleja, P.; Charlaix, T.; Rizzardo, P.; Janel, N. Energy specificity of rock climbing and aerobic capacity in competitive sport rock climbers. J. Sports Med. Phys. Fitness 1995, 35, 20-24. [PubMed]

5. Aicale, R.; Tarantino, D.; Maffulli, N. Overuse injuries in sport: A comprehensive overview. J. Orthop. Surg. 2018, 13, 309. [CrossRef]

6. Hainline, B.; Derman, W.; Vernec, A.; Budgett, R.; Deie, M.; Dvořák, J.; Harle, C.; Herring, S.A.; McNamee, M.; Meeuwisse, W.; et al. International olympic committee consensus statement on pain management in elite athletes. Br. J. Sports Med. 2017, 51, 1245-1258. [CrossRef]

7. Kosek, E.; Clauw, D.; Nijs, J.; Baron, R.; Gilron, I.; Harris, R.E.; Mico, J.-A.; Rice, A.S.C.; Sterling, M. Chronic nociplastic pain affecting the musculoskeletal system: Clinical criteria and grading system. Pain 2021, 162, 2629-2634. [CrossRef]

8. Crabtree, D.; Ganty, P. Common functional pain syndromes. BJA Educ. 2016, 16, 334-340. [CrossRef]

9. Cliton Bezerra, M.; Valentim Bittencourt, J.; Reis, F.J.J.; de Almeida, R.S.; Meziat-Filho, N.A.M.; Nogueira, L.A.C. Central sensitization inventory is a useless instrument for detection of the impairment of the conditioned pain modulation in patients with chronic musculoskeletal pain. Joint Bone Spine 2021, 88, 105127. [CrossRef]

10. Woollings, K.Y.; McKay, C.D.; Emery, C.A. Risk factors for injury in sport climbing and bouldering: A systematic review of the literature. Br. J. Sports Med. 2015, 49, 1094-1099. [CrossRef]

11. Grønhaug, G.; Norberg, M. First overview on chronic injuries in sport climbing: Proposal for a change in reporting of injuries in climbing. BMJ Open Sport Exerc. Med. 2016, 2, e000083. [CrossRef]

12. McDonald, J.W.; Henrie, A.M.; Teramoto, M.; Medina, E.; Willick, S.E. Descriptive epidemiology, medical evaluation, and outcomes of rock climbing injuries. Wilderness Environ. Med. 2017, 28, 185-196. [CrossRef] [PubMed]

13. Wegner, L.; Pagel, J.E.; Smit, A.W.; Straszacker, A.; Swart, S.L.; Taft, S.J. Common neuromusculoskeletal injuries amongst rock climbers in the Western Cape. S. Afr. J. Physiother. 2015, 71, 227. [CrossRef] [PubMed]

14. Grønhaug, G.; Saeterbakken, A. No pain no gain: A Survey of use of healthcare and reasons not to seek healthcare by Norwegian climbers with chronic injuries. BMJ Open Sport Exerc. Med. 2019, 5, e000513. [CrossRef] [PubMed]

15. Folkl, A.K. Characterizing the consequences of chronic climbing-related injury in sport climbers and boulderers. Wilderness Environ. Med. 2013, 24, 153-158. [CrossRef] [PubMed]

16. Grønhaug, G. Self-reported chronic injuries in climbing: Who gets injured when? BMJ Open Sport Exerc. Med. 2018, 4, e000406. [CrossRef]

17. Levernier, G.; Laffaye, G. Rate of force development and maximal force: Reliability and difference between non-climbers, skilled and international climbers. Sports Biomech. 2021, 20, 495-506. [CrossRef]

18. Seifert, L.; Wolf, P.; Schweizer, A. (Eds.) The Science of Climbing and Mountaineering; Routledge: London, UK, 2016; ISBN 978-1-315-68243-3.

19. Vigouroux, L.; de Monsabert, B.G.; Berton, E. Estimation of hand and wrist muscle capacities in rock climbers. Eur. J. Appl. Physiol. 2015, 115, 947-957. [CrossRef]

20. Bartolomei, S.; Grillone, G.; di Michele, R.; Cortesi, M. A Comparison between male and female athletes in relative strength and power performances. J. Funct. Morphol. Kinesiol. 2021, 6, 17. [CrossRef]

21. Saul, D.; Steinmetz, G.; Lehmann, W.; Schilling, A.F. Determinants for success in climbing: A systematic review. J. Exerc. Sci. Fit. 2019, 17, 91-100. [CrossRef]

22. Chen, C.K.; Nizar, A.J. Myofascial Pain syndrome in chronic back pain patients. Korean J. Pain 2011, 24, 100-104. [CrossRef]

23. Bartley, E.J.; Fillingim, R.B. Sex differences in pain: A brief review of clinical and experimental findings. BJA Br. J. Anaesth. 2013, 111, 52-58. [CrossRef] [PubMed]

24. Basford, J.R.; An, K.-N. New techniques for the quantification of fibromyalgia and myofascial pain. Curr. Pain Headache Rep. 2009, 13, 376-378. [CrossRef] [PubMed]

25. Severino, S.K.; Moline, M.L. Premenstrual syndrome. Obstet. Gynecol. Clin. N. Am. 1990, 17, 889-903. [CrossRef]

26. Zuil-Escobar, J.C.; Martínez-Cepa, C.B.; Martín-Urrialde, J.A.; Gómez-Conesa, A. The prevalence of latent trigger points in lower limb muscles in asymptomatic subjects. PMR 2016, 8, 1055-1064. [CrossRef] [PubMed]

27. Logan, A.J.; Makwana, N.; Mason, G.; Dias, J. Acute hand and wrist injuries in experienced rock climbers. Br. J. Sports Med. 2004, 38, 545-548. [CrossRef]

28. Gordon, R.; Bloxham, S. A systematic review of the effects of exercise and physical activity on non-specific chronic low back pain. Healthcare 2016, 4, 22. [CrossRef] 
29. Schinhan, M.; Neubauer, B.; Pieber, K.; Gruber, M.; Kainberger, F.; Castellucci, C.; Olischar, B.; Maruna, A.; Windhager, R.; Sabeti-Aschraf, M. Climbing has a positive impact on low back pain: A prospective randomized controlled trial. Clin. J. Sport Med. Off. J. Can. Acad. Sport Med. 2016, 26, 199-205. [CrossRef]

30. Engbert, K.; Weber, M. The effects of therapeutic climbing in patients with chronic low back pain: A randomized controlled study. Spine 2011, 36, 842-849. [CrossRef]

31. Fett, D.; Trompeter, K.; Platen, P. Prevalence of back pain in a group of elite athletes exposed to repetitive overhead activity. PLoS ONE 2019, 14, e0210429. [CrossRef] 